\title{
Article
}

Doi 10.5943/sif/4/1/6

\section{Foliose lichens along the trails of Casaroro Falls and Pulangbato Falls in Valencia, Negros Oriental, Philippines}

\author{
Paguirigan JAG, Bernal KD, Dayto CGA, Ramos MED, Vigo GDS, dela Cruz \\ TEE
}

Department of Biological Sciences, College of Science, University of Santo Tomas, España 1015 Manila, Philippines

Paguirigan JAG, Bernal KD, Dayto CGA, Ramos MED, Vigo GDS, dela Cruz TEE 2019 - Foliose lichens along the trails of Casaroro Falls and Pulangbato Falls in Valencia, Negros Oriental, Philippines. Studies in Fungi 4(1), 43-49, Doi 10.5943/sif/4/1/6

\begin{abstract}
Lichens are abundant and highly diverse in tropical areas such as the Philippines due to its climate and geographical features. However, several regions of the country remained underexplored or unexplored and many species remained undiscovered in the country's many unique habitats. This study determines the occurrence of foliose lichens in Casaroro Falls and Pulangbato Falls in Valencia, Negros Oriental, Philippines. The lichen morphologies were characterized using available taxonomic keys. Among the 26 lichen samples collected from the two falls, 23 specimens were identified based on their morphological and biochemical characteristics. Of these, 8 species were specific to Casaroro Falls and 13 species to Pulangbato Falls, with only 2 species of lichens found on both waterfalls. Interestingly, 17 species are new records for the Philippines.
\end{abstract}

Key words - foliose - lichen identification - Negros Oriental - new records - Philippines - tropics

\section{Introduction}

Lichens, a mutualism of algae or cyanobacteria (photobiont) and fungi (mycobiont) are abundant in tropical areas such as the Philippines, which shows a wide array of lichen diversity due to its climatic conditions and geographical features (Bawingan et al. 2017). With its tropical climate are various forest ecosystems including lowland rainforest, montane-mossy forests, pine forest, and coastal or mangrove forests where various lichen species could thrive. Although the ideal climatic conditions and geographic isolation of the country resulted in high endemicity among its flora and fauna (Catibog-Sinha \& Heaney 2006), the country is also classified as one of the most threatened ecosystems in the planet. Though known as a megahotspot of biodiversity, the Philippines' vast majority of lichens remained unexplored. So far, the most comprehensive listing of lichens for the country was done by Gruezo (1979) where he noted 1,108 taxa distributed in 137 genera, 789 species, 3 subspecies, 153 varieties, 28 formae and 1 subforma. Although in recent years, lichenology in the Philippines has progress beyond species list to diversity, biomonitoring and bioactivities (Santiago et al. 2010, 2013, de Jesus et al. 2016, Gazo et al. 2019), several regions of the country remained underexplored or unexplored and many species remained undiscovered in many of its unique habitats. This necessitates an urgent assessment of the country's biodiversity including its poorly documented lichen species. Thus, this paper looks at the occurrence of lichen species in Casaroro Falls and Pulangbato Falls in Valencia, Negros Oriental, Philippines. 


\section{Materials and Methods}

\section{Collection Sites}

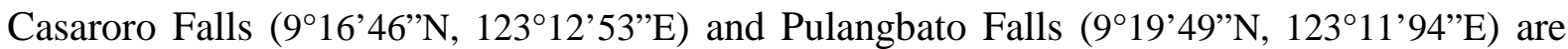
both found in the municipality of Valencia, which is located 9 kilometers west of Dumaguete City. Valencia was voted in 2007 as "the greenest and cleanest" town in the Negros Oriental province. The municipality occupies an area of 14,749 hectares, $65 \%$ are mountainous with elevations ranging from 200 to 500 meters above sea level. It has a cooler climate than the average of the other municipalities because of its higher elevation.

\section{Lichen Collection}

Two waterfalls in the municipality of Valencia, i.e. Casaroro Falls and Pulangbato Falls, were explored for the lichens with help of personnel from the Department of Environment and Natural Resources (DENR). Foliose lichens collected along the trails leading to the waterfalls were placed in brown paper bags, air-dried and then stored in dry wooden cabinets. Storage of voucher specimens were done at the UST Central Laboratories, University of Santo Tomas in Manila, Philippines.

\section{Identification of the Lichens}

Morphological characters and reproductive structures including sections of the thallus and ascocarps were examined using compound and dissecting microscopes. The chemistry of the lichens was determined using the spot test reagents such as potassium hydroxide (K test), iodine (I test), and sodium hypochlorite (C test) as described in Galinato et al. (2017). Based on the observed morpho-anatomic features and lichen chemistry, the specimens were identified with the help of available taxonomic keys and various references, e.g. Gruezo 1979, Goward et al. 1994, Malcolm et al. 2011, Santiago et al. 2013, McCarthy 2015.

\section{Results}

\section{The collected foliose lichens}

A total of 26 foliose lichen specimens were collected from the two waterfalls, Casaroro Falls and Pulangbato Falls. Rocks served as the substratum for the specimens collected in the two sampling locations. Following comparison of their morphological and biochemical characteristics with published reference lichens, 23 specimens in this study were identified and confirmed up to the species level. Three specimens could not be identified with certainty, and thus, were not reported here. The species in bold are new records for the Philippines.

Collema crispum (Huds.) Weber ex F.H. Wigg. (Collemataceae)

= Blennothallia crispa (Weber ex F.H. Wigg.) Otálora, P.M. Jørg. \& Wedin

Specimens examined: Casaroro Falls, Valencia 9'16’43”N, 12312'20”E, 470 masl; Pulangbato Falls, Valencia 9¹9’20”N, 123¹1’39’E, 400masl.

Collema flaccidum (Ach.) Ach. (Collemataceae)

Specimen examined: Pulangbato Falls, Valencia 9¹9'16’’N, 123¹1’32'’E, 430 masl.

Collema rugosum Kremp. (Collemataceae)

Specimen examined: Pulangbato Falls, Valencia 9¹9’16’’N, 12311’32’’E, 430 masl.

Collema texanum Tuck. (Collemataceae)

Specimen examined: Pulangbato Falls, Valencia 9¹9’20’N, 12311’39’E, 400 masl.

Dermatocarpon miniatum (L.) W. Mann (Verrucariaceae) 
= Dermatocarpon miniatum var. miniatum (L.) W. Mann

Specimens examined: Casaroro Falls, Valencia 9¹6’43”N, 12312’20”E, 470 masl.

Dermatocarpon moulinsii (Mont.) Zahlbr (Verrucariaceae)

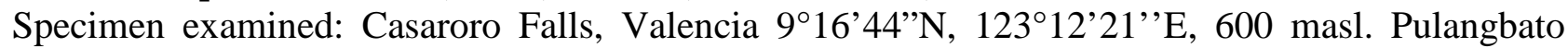
Falls, Valencia 9॰19'16’’N, 12311'32'’E, 430 masl.

Dermatocarpon rivulorum (Arnold) Dalla Torre \& Sarnth. (Verrucariaceae)

Specimen examined: Pulangbato Falls, Valencia 9¹9’16’’N, 123¹1’32’’E, 430masl.

Leioderma sorediatum D.J. Galloway \& P.M. Jørg. (Pannariaceae)

Specimen examined: Pulangbato Falls, Valencia 9¹9’20”N, 12311’39”E, 400masl.

Leptogium adpressum Nyl. (Collemataceae)

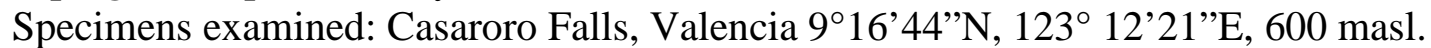

Leptogium brebissonii Mont. (Collemataceae)

Specimens examined: Casaroro Falls, Valencia 9¹6’44”N, 123¹2’21’E, 600 masl.

Leptogium californicum Tuck. (Collemataceae)

Specimen examined: Casaroro Falls, Valencia 9¹6’43”N 12312’20”E, 470masl.

Leptogium corticola (Taylor) Tuck. (Collemataceae)

Specimens examined: Casaroro Falls, Valencia 9¹6’44”N 123 12’21”E, 600masl.

Leptogium cyanescens (Rabenh.) Körb. (Collemataceae)

Specimens examined: Casaroro Falls, Valencia 9¹6’44”N 123 12’21”E, 600 masl.

Leptogium subaridum P.M. Jørg. \& Goward (Collemataceae)

Specimens examined: Pulangbato Falls, Valencia 9¹9'16’’N 12311'32'’E, 430 masl.

Nephroma isidiosum (Nyl.) Gyeln. (Nephromataceae)

Specimen examined: Casaroro Falls, Valencia 9¹6’43’N 12312’20”E, 470 masl.

Pannaria lurida (Mont.) Nyl. (Pannariaceae)

Specimens examined: Pulangbato Falls, Valencia 9¹9'16’’N 123¹1’32'’E, 430 masl.

Pannaria maritima P.M. Jørg. (Pannariaceae)

Specimens examined: Casaroro Falls, Valencia 9¹6’44’N 123 12’21’E, 600 masl.

Parmotrema saccatilobum (Taylor) Hale (Parmeliaceae)

Specimens examined: Pulangbato Falls, Valencia 9¹9'16’’N 12311'32'’E, 430 masl.

Physcia clementei (Turner) Lynge (Physciaceae)

Specimens examined: Pulangbato Falls, Valencia 9¹9’20”N 12311’39”E, 400 masl.

Physcia grisea (Lam.) Zahlbr. (Physciaceae)

Specimens examined: Pulangbato Falls, Valencia 9¹9'16’’N 12311’32'’E, 430 masl.

Pyxine cylindrica Kashiw. (Caliciaceae)

Specimens examined: Pulangbato Falls, Valencia 9¹9'16’’N 123¹1’32'’E, 430 masl. 
Pyxine keralensis D.D. Awasthi (Caliciaceae)

Specimens examined: Pulangbato Falls, Valencia 9¹9’16’’N 12311’32’’E, 430 masl.

Pyxine philippina Vain. (Caliciaceae)

Specimens examined: Pulangbato Falls, Dumaguete City 9¹9’16’’N 123¹1’32’’E, 430masl.

\section{Discussion}

The thalli of the identified foliose lichens in Fig. 1 were collected from both Casaroro and Pulangbato Falls. These lichen thalli included those taxa from the genera Collema, Dermatocarpon, Leptogium, and Pannaria. Only Collema crispum was identified from Casaroro Falls while 4 species of Collema including C. texanum, C. crispum, C. flaccidum, and C. rugosum were recorded in Pulangbato Falls. Dermatocarpon moulinsii and Collema crispum were present in the two sites. Leptogium species including L. adressum, L. brebissonii, L. califernicum, L. corticola, and L. cyanescens were numerous in Casaroro Falls, i.e. at least half of the identified foliose lichens in that site. Leptogium subaridum was recorded in Pulangbato falls. Pannaria maritima was noted in Casaroro Falls while Pannaria lurida was from Pulangbato Falls. The only unique lichen recorded in Casaroro Falls was Nephroma isidiosum, while species of Pyxine, i.e., P. cylindrica, P. keralensis, P. philippina, P. grisea, P. clementei, and Parmotrema saccatilobum and Leioderma sorediatum were solely identified in Pulangbato Falls. The species observed here were also previously reported in other Asian countries, e.g. Collema crispum in China, Dermatocarpon miniatum in Japan (Harada 1993), Leioderma sorediatum in India and Thailand (Jørgensen 2002), Leptogium cyanescens in South Korea (Jayalal et al. 2014) and Thailand (Wolseley et al. 2002), Parmotrema saccatilobum in Thailand (Wolseley et al. 2002), Pyxine keralensis in Sri Lanka (Weerakoon \& Aptroot 2016), and Pyxine cylindrica in India (Nayaka \& Upreti 2005). Fig. 2 shows the distribution of the collected lichens on the two sampling localities.

Lichens differ remarkedly from higher plants. Due to their poikilohydrous nature, lichens tend to be susceptible to various environmental factors which results to changes in genetic, individual, population and community levels (Shukla et al. 2014). For instance, the microclimatic conditions of an area, e.g., precipitation, light, humidity and dryness, air quality and wind currents, play an important role in the successful colonization of lichens (Shukla et al. 2014). In this study, the abundance of foliose lichens in both Casaroro and Pulangbato Falls can be attributed to the clean air and moist environment in the sampling localities. The moist environment enhances the growth and development of lichens (Armstrong 2015). Clean air also contributed to their abundant growth, as lichens tend to absorb harmful chemicals through their cortex. Between the two collecting sites, Casaroro Falls had the most number of Leptogium species, perhaps because of the humidity in the area, which is essential for Leptogium species to survive (Armstrong 2015).

Altitude could also influence the occurrence of lichen species in a community (Armstrong 2015), which means that, "the higher the elevation, the more diverse the lichen species are". As inferred from this study, five Leptogium species were found in Casaroro Falls at 600 meters in elevation as compared to one species of Leptogium in Pulangbato Falls at 400 meters. However, more species of Collema were collected in Pulangbato Falls. A high number of foliose lichens were also noted for Pulangbato Falls, e.g. Pyxine, Physcia, Parmotrema, and Leioderma, which may be due to favorable temperature, humidity and light intensity. Lesser number of taxa in Casaroro Falls may also be attributed to some man-made activities, as the area is slightly disturbed due to ecotourism. According to Newsome and Hughes (2016), potential negative impacts of tourism on biodiversity often interact with wider landscape-level impacts that compromise biodiversity conservation. 


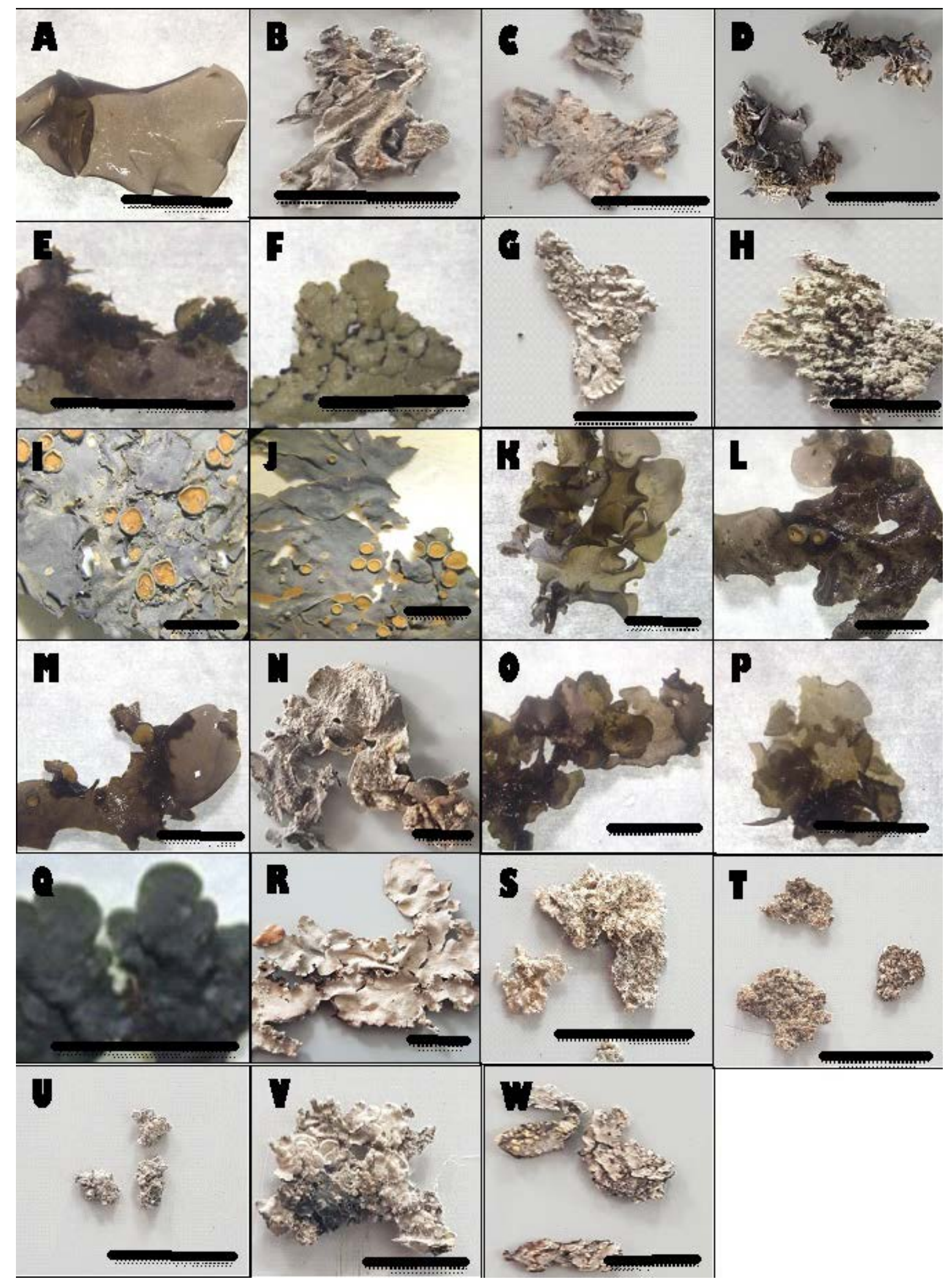

Fig. 1 - Thallus of identified foliose lichens from Casaroro Falls and PulangBato Falls. A Collema crispum. B Collema flaccidum. C Collema rugosum. D Collema texanum. E Dermatocarpon miniatum. F Dermatocarpon moulinsii. G Dermatocarpon rivulorum. $\mathrm{H}$ Leioderma sorediatum. I Leptogium adpressum. J Leptogium brebissonii. K Leptogium califernicum. L Leptogium corticola. M Leptogium cyanescens. $\mathrm{N}$ Leptogium subaridum. O Nephroma isidiosum. P Pannaria lurida. Q Pannaria maritime. R Parmotrema saccatilobum. S Physcia clementei. T Physcia grisea. U Pyxine cylindrical. V Pyxine keralensis. W Pyxine philippina. Scale Bars: A-W=5 mm. 
Dermatocarpon miniatum Leptogium adpressum Leptogium brebissonii Leptogium californicum Leptogium corticola Leptogium cyanescens Nephroma isidiosum Pannaria maritima

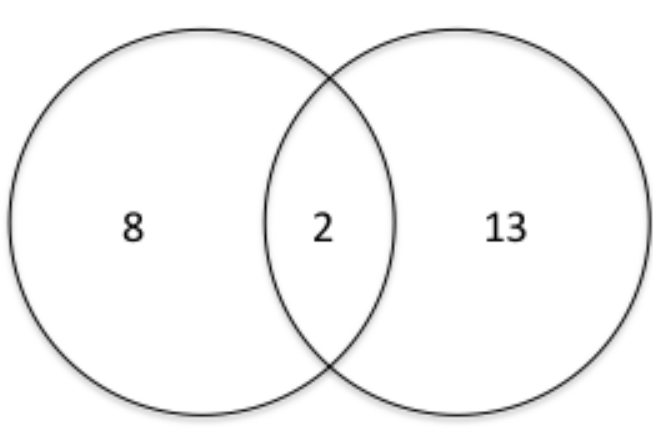

Collema crispum

Dermatocarpon moulinsii
Collema flaccidum

Collema rugosum

Collema texanum

Dermatocarpon rivulorum

Leioderma sorediatum

Leptogium subradum

Pannaria lurida

Parmotrema saccatilobum

Physcia clementei

Physcia grisea

Pyxine cylindrica

Pyxine keralensis

Pyxine philippina

Fig. 2 - Distribution of lichen species in Casaroro and Pulang Bato Falls in Valencia, Negros Oriental.

\section{Conclusions}

Of the 23 lichen taxa identified in this study, 17 species are new records for the Philippines. The identification of new records as exemplified in this study highlighted the importance of conducting species survey for documenting the hidden diversity in any given area. This study is also the first report of lichens in the municipality of Valencia.

\section{Acknowledgement}

We would like to thank Ms. Krystle Angelique A. Santiago for her valuable comments and the members of the Fungal Biodiversity, Ecogenomics, and Systematics (FBeS) group at the Research Center for Natural and Applied Sciences (RCNAS), University of Santo Tomas for their technical support during the field collection.

\section{Disclosure Statement}

There is NO potential conflict of interest that was reported by the authors.

\section{References}

Armstrong RA. 2015 - The influence of environmental factors on the growth of lichens in the field. In: Recent Advances in Lichenology: Modern Methods and Approaches in Biomonitoring and Bioprospection (DK Upreti, PK Divakar, V Shukla, R Bajpal, eds). New Delhi: Springer, pp. 1-18. Doi: 10.1007/978-81-322-2181-4_1.

Bawingan P, Lardizaval MP, Rosuman PF. 2017 - Philippine species of Parmotrema (Ascomycota, Parmeliaceae). Philippine Journal of Science (146) 2: 145-158.

Catibog-Sinha CS, Heaney LR. 2006 - Philippine Biodiversity: Principles and Practice. Quezon City: Haribon Foundation.

de Jesus EE, Hur JS, Notarte KIR, Santiago KAA, dela Cruz TEE. 2016 - Antibacterial, antioxidant and cytotoxic activities of the corticolous lichens Canoparmelia aptata, Pannaria sp., and Parmotrema gardneri collected from Mt. Banahaw, Quezon, Philippines. Current Research on Environmental and Applied Mycology 6(3): 173-183.

Gazo SMT, Santiago KAA, Tjitrosoedirjo SS, dela Cruz TEE. 2019 - Antimicrobial and herbicidal activities of the fruticose lichen Ramalina from Guimaras Island, Philippines. Biotropia 26 (1): 23-32. 
Galinato MGM, Mangubat CB, Leonor DS, Cababa GRC, Cipriano BPS, Santiago KAA. 2017 Identification and diversity of the fruticose lichen Usnea in Kalinga, Luzon Island, Philippines. Current Research in Environmental and Applied Mycology 7(4): 249-257.

Goward T, McCune B, Meidinger DV. 1994 - The Lichens of British Columbia - Illustrated Keys

Part I. Foliose and Squamulose Species. Special series 08, British Columbia: Ministry of

Forest Reserch Program.

Gruezo WS. 1979 - Compendium of Philippine lichens. Kalikasan, Philippine Journal of Biology. 8: 267-300.

Harada H. 1993 - A taxonomic study on Dermatocarpon and its allied genera (Lichenes, Verucariaceae) in Japan. Natural History Research 2 (2): 113-152.

Jayalal U, Hwa Jang S, Yu NH, Oh SO, Hur JS. 2014 - Notes on the lichen Genus Leptogium (Collemataceae, Ascomycota) in South Korea. Mycobiology 42 (2): 120-131.

Jørgensen PM. 2002 - Further notes on Asian species of the lichen genus Fuscopannaria. Journal of the Hattori Botanical Laboratory 92: 225-229.

Malcolm B, Malcolm N, Knight A. 2011 - New Zealand Foliose Lichens - An Illustrated Key. New Zealand: Micro Optics Press.

McCarthy PM. 2015 - A new species of Lithothelium (lichenized Ascomycota, Pyrenulaceae) from the Tarkine region, north-western Tasmania. Telopea 18: 167-170.

Nayaka S, Upreti DK. 2005 - Status of lichen diversity in Western Ghats, India. Sahyadri E-News, Western Ghats Biodiversity Information System Issue 16.

Newsome D, Hughes M. 2016 - Understanding the impacts of ecotourism on biodiversity: a multiscale, cumulative issue influenced by perceptions and politics. In: Handbook on biodiversity and ecosystem services in impact assessment. Cheltenham (UK): Edward Elgar Publishing, pp. 276-298.

Santiago KA, Borricano JN, Canal J, Marcelo DM, Perez MC, dela Cruz TEE. 2010 Antimicrobial activities of selected fruticose lichens from different sites in Luzon. Philippine Science Letters 3(2): 18-29.

Santiago KAA, Sangvichien E, Boonpragob K, dela Cruz TEE. 2013 - Secondary metabolic profiling and antibacterial activities of different species of Usnea collected in Northern Philippines. Mycosphere 4(2): 267-280.

Shukla V, Upreti DK, Bajpai R. 2014 - Lichens to biomonitor the environment. New Delhi: Springer.

Weerakoon G, Aptroot A. 2016 - Nine new lichen species and 64 new records from Sri Lanka. Phytotaxa 280 (2): 152-162.

Wolseley P, Aguirre-Hudson B, McCarthy P. 2002 - Catalogue of the lichens of Thailand. Bulletin of the Natural History Museum. Botany Series. 32(1): 13-59. 